\title{
JOHN BAILLIE HENDERSON: A HYDROLOGIST IN COLONIAL BRISBANE
}

MARGARET COOK

University of Queensland

\section{Abstract}

John Baillie Henderson, Queensland Government Hydraulic Engineer (1883-1914), influenced the development of hydrology in south-east Queensland by successfully combining state imperatives with an understanding of the local environment. Science became entwined with nation-building where the applied nature of hydrological engineering fostered development and addressed local concerns in a region characterised by drought and flood. Henderson, as part of a global scientific community, appreciated the importance of local climatic variation and substantially increased hydrological knowledge in Queensland at the turn of the twentieth century.

Keywords: John Baillie Henderson, hydrology, Queensland, science

\section{Introduction}

Since at least the late eighteenth century, new settlers to Australia brought climatic knowledge as cultural baggage, against which they measured and analysed their new environment, often erroneously. British immigrants were familiar with relatively low variability in annual rainfall and droughts measured in days, not years. ${ }^{1}$ Experience in India and other colonies did not make them more prepared for Australian conditions. Settlers arriving in the Moreton Bay penal settlement (now Brisbane), established in 1824 and opened for free settlement in 1842, took some time to understand a subtropical climate characterised by a high rainfall variability, long droughts, cyclone-induced monsoonal rain and severe floods. In Australian settler historiography, the environment is frequently portrayed as unfamiliar, alien and

\footnotetext{
1 I wish to thank Melissa Harper, Peter Spearritt, Jodi Frawley, Ruth Morgan, Alessandro Antonello, Lilian Pearce, Libby Robin, Emily O'Gorman and two anonymous reviewers for assistance and comments on earlier drafts. I acknowledge the funding provided through the Australian Government Research Training Program Scholarship. Tim Sherratt, 'Human Elements', in A Change in the Weather: Climate and Culture in Australia, ed. Tim Sherratt, Tom Griffiths and Libby Robin (Canberra: National Museum of Australia, 2005), 1-17; James Beattie, Emily O'Gorman and Matthew Henry, 'Introduction', in Climate, Science and Colonization: Histories from Australia and New Zealand, ed. James Beattie, Emily O’Gorman and Matthew Henry (New York: Palgrave Macmillan, 2014), 1.
} 
'unknowable', and the settler as environmentally ignorant and arrogant. ${ }^{2}$ Although historians recognise the importance of climate in shaping the settler experience, ${ }^{3}$ the 'failure to learn' narrative persists. ${ }^{4}$ The opposing view maintains that settlers did learn and were prepared to adapt. ${ }^{5}$ As historians Emily O'Gorman, Kirsty Douglas and Grace Karskens have shown, necessity, labour, time and lived experience helped settlers acquire informal local climatic knowledge, recorded by memory and oral history, but it remained the role of colonial scientists in the nineteenth century to officially record and codify the unfamiliar climatic patterns for the state. ${ }^{6}$

Throughout the British Empire, a network of meteorologists became what O'Gorman describes as the 'formalisers of environmental knowledge'. Australian colonies appointed meteorologists after 1856, who were charged with the task of deciphering the continent's weather patterns and forecasting droughts and floods for settlerswork that was fundamental to colonial state-building through the centralisation of scientific expertise. ${ }^{8}$ Meteorologists became closely aligned with hydraulic engineers as the latter required the same knowledge of rainfall and run-off for the purposes of irrigation, water conservation and supply, as well as flood mitigation schemes. While meteorologists have attracted scholarly attention in this regard, the discipline

2 This trend is noted in the Mallee district by Katie Holmes and Kylie Mirmohamadi, 'Howling Wilderness and Promised Land: Imagining the Victorian Mallee 1840-1914', Australian Historical Studies 46, no. 2 (2015): 192, doi.org/10.1080/1031461X.2015.1037320; and by Grace Karskens in the Hawkesbury-Nepean region, 'Floods and Flood-mindedness in Early Colonial Australia', Environmental History 21 (2016): 317-18, doi.org/10.1093/ envhis/emv186.

3 Sherratt, Griffiths and Robin, A Change in the Weather; Kirsty Douglas, "For the Sake of a Little Grass": A Comparative History of Settler Science and Environmental Limits in South Australia and the Great Plains', in Climate, Science and Colonization, ed. Beattie, O'Gorman and Henry, 99-118; Claire Fenby, Don Garden and Joëlle Gergis, "The usual weather in New South Wales is uncommonly bright and clear ... equal to the finest summer day in England”: Flood and drought in New South Wales, 1788-1815', Climate, Science and Colonization, ed. Beattie, O'Gorman and Henry, 43-60; Don Garden, Droughts, Floods and Cyclones: El Niños that Shaped Our Colonial Past (North Melbourne: Australian Scholarly Publishing, 2009); David Day, The Weather Watchers: 100 Years of the Bureau of Meteorology (Melbourne: Melbourne University Publishing, 2007).

4 Karskens, 'Floods and Flood-mindedness in Early Colonial Australia', 317-18.

5 Karskens, 'Floods and Flood-mindedness in Early Colonial Australia', 315-42; Grace Karskens, The Colony: A History of Early Sydney (Crows Nest, NSW: Allen \& Unwin, 2009); James Beattie and Ruth Morgan, 'Engineering Edens on This "Rivered Earth"? A Review Article on Water Management and Hydro-Resilience in the British Empire, 1860s-1940s', Environment and History 23 (2017): 53, doi.org/10.3197/096734017X14809635325593.

6 Emily O'Gorman, 'Colonial Meteorologists and Australia's Variable Weather', University of Queensland Historical Proceedings 16 (2005): 67-87; Douglas, “'For the Sake of a Little Grass”, 99-117; Emily O’Gorman, “'Soothsaying” or Science?: H.C. Russell, Meteorology, and Environmental Knowledge of Rivers in Colonial Australia', in Climate, Science and Colonization, ed. Beattie, O'Gorman and Henry, 177-93. This link with learning and nature through time, experience and labour has been identified by James C. Scott, Seeing Like A State: How Certain Schemes to Improve the Human Condition Have Failed (New Haven, CT: Yale University Press, 1998); Richard White, The Organic Machine: The Remaking of the Columbia River, (New York: Hill and Wang, 1995); Sherratt, 'Human Elements', 4.

7 O'Gorman, 'Colonial Meteorologists and Australia's Variable Weather', 67-87.

8 O’Gorman, 'Colonial Meteorologists and Australia’s Variable Weather', 67. 
of hydraulic engineering has gone relatively unexplored. ${ }^{9}$ This article considers the career of John Baillie Henderson, Queensland's first Hydraulic Engineer, to explore how state agencies substantially contributed to settler understandings of local climates and environments. By studying Henderson's work and its implications for hydrological management, this article challenges the 'failure to learn' narrative of Australian settler environmental history.

Like meteorology, hydrology is a transnational science. As the historian David Livingstone notes, the development of a science like hydrology 'has been inextricably bound up with travelling to distant realms ${ }^{10}$ Scholars have shown that after British colonisation, the Australasian colonies did not undergo isolated development, but rather were connected through complex networks across the Tasman Sea and beyond. These networks of exchange allowed for the sharing of scientific knowledge through the new technologies of the telegraph, railways and steamships, as well as newspapers, journals and scientific meetings. ${ }^{11}$ During his term in Queensland, Henderson's gathering and dissemination of local scientific data contributed to the development of state, national and international hydrological and meteorological knowledge at the turn of the twentieth century.

This article sits within a large body of scholarship linking engineering and technology with attempts to harness, tame and control nature (in this case, the hydrological flow of rivers) to reduce environmental threats to the pursuit of human progress. ${ }^{12}$ Throughout the British Empire, hydraulic engineers were employed to shape colonial hydrologies and to impose their 'technological-environmental system on the landscape'. ${ }^{13}$ In this way, science and technology formed a partnership to fulfil

9 O'Gorman, 'Colonial Meteorologists and Australia's Variable Weather', 67-87; Beattie and Morgan, 'Engineering Edens on This "Rivered Earth"?, 44; O’Gorman, “'Soothsaying” or Science?', 180; David Day, The Weather Watchers; Kirsty Douglas, “Under such sunny skies”: Understanding weather in Colonial Australia, 1860-1901', Metarch Papers 17 (2007); Katharine Anderson, 'Practical Science: Meteorology and the Forecasting Controversy in Mid-Victorian Britain' (PhD diss., Northwestern University, 1994); W. J. Gibbs, 'The Origins of Australian Meteorology', Metarch Papers 12 (June 1998).

10 David Livingstone, Putting Science in its Place: Geographies of Scientific Knowledge (Chicago: University of Chicago Press, 2003), 142.

11 Eric Pawson and Tom Brooking, 'Introduction', in Making a New Land: Environmental Histories of New Zealand, ed. Eric Pawson and Tom Brooking (Dunedin: Otago University Press, 2013), 23; Douglas, 'Under such sunny skies'.

12 Emily O'Gorman, Flood Country: An Environmental History of the Murray-Darling Basin (Collingwood: CSIRO Publishing, 2012); Michael Cathcart, The Water Dreamers: The Remarkable History of Our Dry Continent (Melbourne: Text Publishing, 2009); Sara Pritchard, Confluence: The Nature of Technology and the Remaking of the Rhône (Cambridge, MA: Harvard University, 2011); David Blackbourn, The Conquest of Nature: Water, Landscape and the Making of Modern Germany (New York: W. W. Norton and Company, 2006); Ari Kelman, A River and its City: The Nature of Landscape in New Orleans (Berkeley, CA: University of California Press, 2003); Mark Everard, The Hydro-Politics of Dams (London: Zed Books, 2013); Beattie and Morgan, 'Engineering Edens on This "Rivered Earth"?'; Karen O’Neill, Rivers by Design: State Power and the Origins of U.S. Flood Control (Durham, NC: Duke University Press, 2006); Marc Cioc, The Rhine: An Eco-Biography, 1815-2000 (Seattle, WA: University of Washington Press, 2001).

13 Beattie and Morgan, 'Engineering Edens on This "Rivered Earth"?', 45; John Brioch, 'Engineering the Empire: British Water Supply Systems and Colonial Societies, 1850-1900', Journal of British Studies 46, 2 (2007): 347. 
the needs of the colonial state. The Australian colonies offered no exception, since in the 1880 s, scientific research earned a higher profile. Governments increasingly viewed science as a state asset with a utilitarian purpose, adding scientists and their accompanying bureaucracies to their administrations. ${ }^{14}$ Government departments for agriculture, stock and water were created to undertake scientific research to ensure the achievement of government objectives. As Libby Robin notes, Australian scientific research has been 'government' science-that is, applied science linked to state imperatives for economic development. Henderson's employer, the Queensland Department of Water Supply, for example, embraced the provision of potable water and flood mitigation as key priorities for progress. ${ }^{15}$ How these issues became entangled with scientific research, technological interventions and local needs during Henderson's tenure is the focus of this study.

\section{John Baillie Henderson}

James (John) Baillie Henderson (Figures 1 and 2) was born in London in 1836; after completing his schooling, he found employment in a solicitor's office. His father felt the lure of the Australian gold rush and, at the age of 16, John found himself in Victoria, with his parents and two siblings. John made money on the Bendigo goldfields, unlike many, including his father, then secured employment in a foundry. His path to engineering was typical of colonial engineers who undertook their training through employment rather than formal education. ${ }^{16}$ Henderson secured a position as road overseer for the Victorian Roads and Bridges Department from 1862 until 1863, when he became a shire engineer in Gippsland in the colony's south-east. He then joined the Victorian Water Supply Department as an engineer and surveyor between 1866 and 1872 . He first worked on the Coliban water scheme near Bendigo, which supplied water to the mining districts and nearby towns, after which he worked on Geelong's water supply. He held various engineering positions in Victoria until January 1878, when 200 employees were dismissed from the Victorian public service. Henderson headed north to the colony of Queensland and, wasting no time, found employment in April 1878 as resident engineer on the northern waterworks in Townsville.

14 Scott, Seeing Like A State, 5-7; Blackbourn, The Conquest of Nature; Sara Pritchard, Confluence; O’Neill, Rivers by Design; Ian Inkster and Jan Todd, 'Support for the scientific enterprise, 1850-1900', in Australian Science in the Making, ed. R. W. Home (Cambridge: Cambridge University Press, 1988), 126.

15 Libby Robin, How a Continent Created a Nation (Sydney: UNSW Press, 2007), 10; Libby Robin, 'Ecology: A Science of Empire?', in Ecology and Empire: Environmental History of Settler Societies, ed. Tom Griffiths and Libby Robin (Seattle, WA: University of Washington Press, 1997), 63-75; Libby Robin, 'Battling the Land and Global Anxiety: Science, Environment and Identity in Settler Australia', PAN: Philosophy, Activism, Nature 7 (2010): 7-8; Libby Robin and Tom Griffiths, 'Environmental History in Australasia', Environment and History 10, no. 4 (2004): 439-74.

16 Practical training rather than university qualifications was the typical path for engineers: R. A. Buchanan, 'Gentlemen Engineers: The Making of a Profession', Victorian Studies 26, no. 4 (1983): 428. 


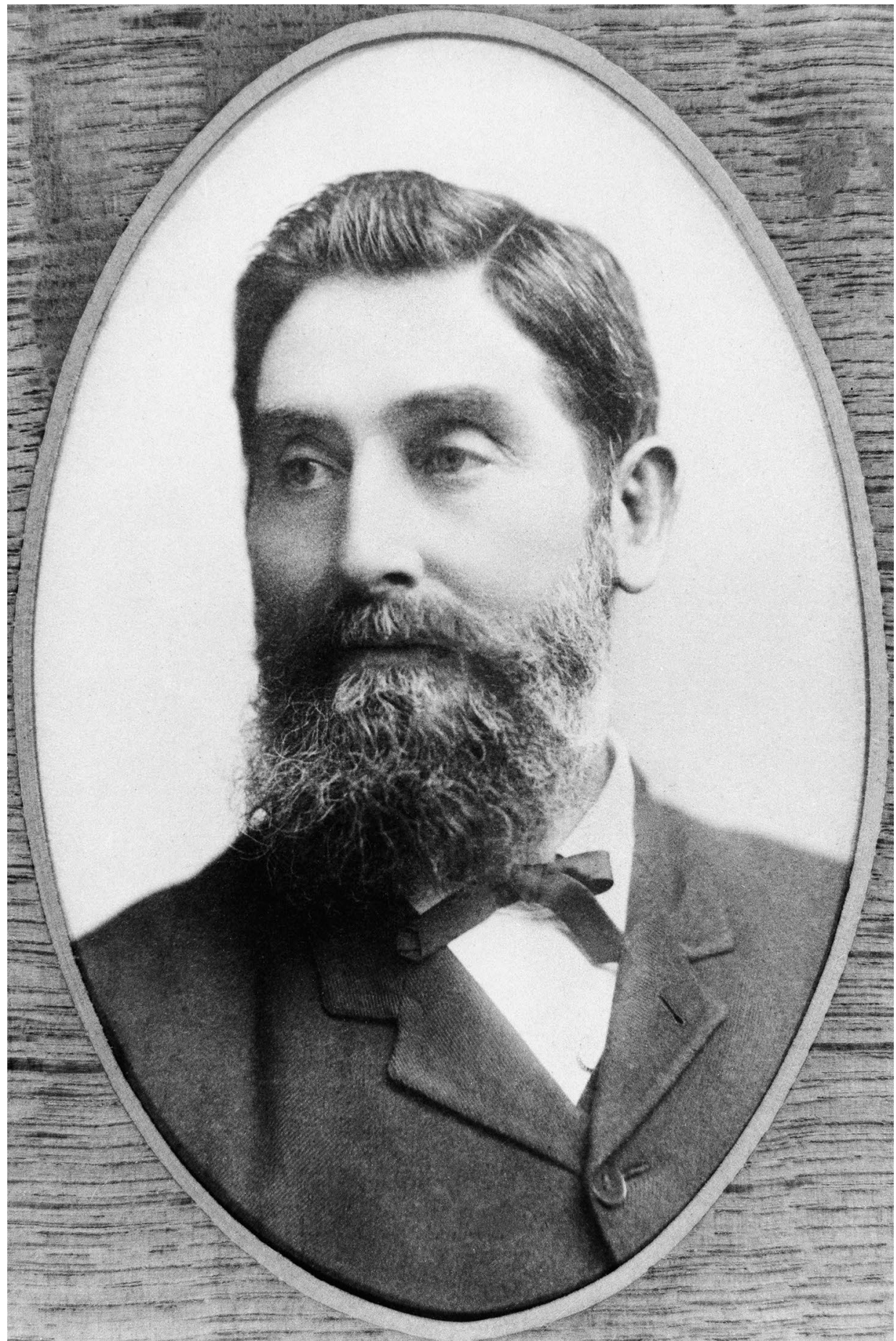

Figure 1: John Baillie Henderson (1836-1921)

Source: State Library of Queensland, Image No. 167210. 


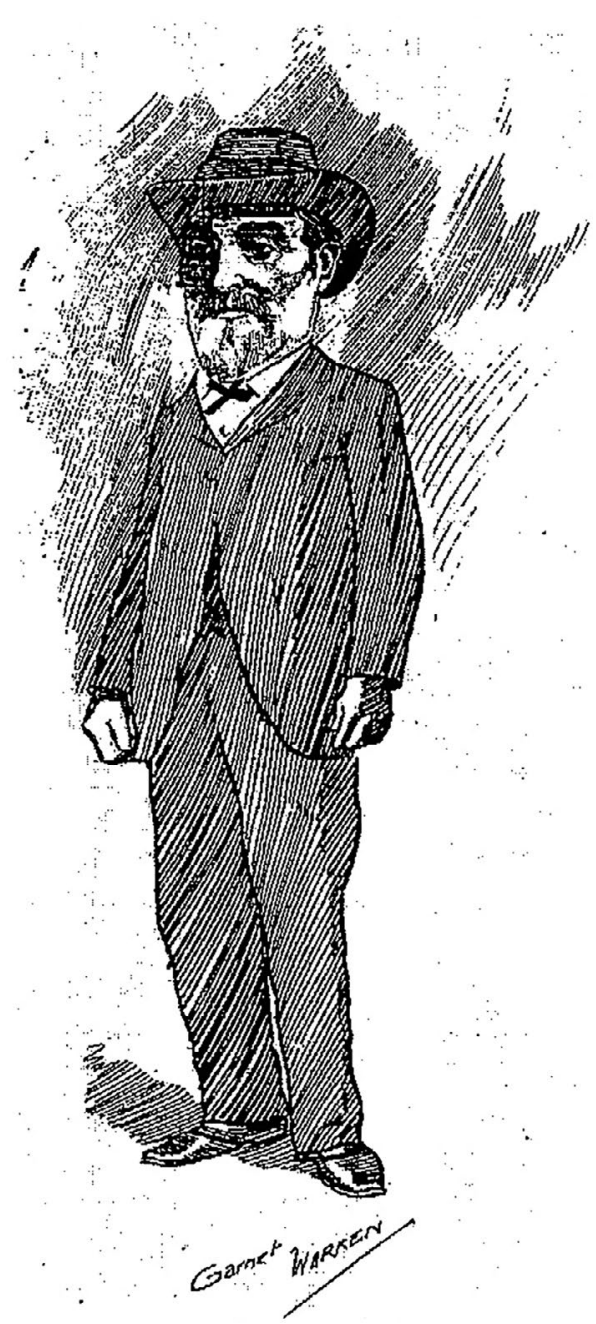

Figure 2: 'Hydraulic Henderson'

Source: The Queenslander, 31 July 1897, 221.
Henderson brought with him extensive practical experience in both the construction and operation of hydraulic works. He was extremely industrious, with incredible stamina and an unrelenting work ethic. Largely self-trained, Henderson's avid reading of international engineering papers gave him sound technical knowledge. ${ }^{17}$ Few engineers in Queensland at the time could claim the same expertise. Always referred to as J. B. Henderson or by his nickname 'Hydraulic Henderson', he earned the respect of his colleagues for his knowledge and hard work. ${ }^{18}$ Henderson's professional credentials were recognised in 1880 with his admission to the Institution of Civil Engineers in London as an Associate Member. He later became a member of civil and mechanical engineers' institutions in Australia and the American Society of Civil Engineers. ${ }^{19}$

In many regards, Henderson fitted the mould of the colonial engineer, both in the strategies he advocated and his attitudes. In regard to mitigating the floods that periodically affected the Queensland capital of Brisbane, he recommended widening and deepening, regulating and damming the river to prevent 'the excesses of Nature', 'ameliorate the evil effects of inundation' and avert 'destruction and misery in

17 Papers on water supply compiled by J. B. Henderson, 1886-96, held in the State Library of Queensland, provide evidence of Henderson's wide reading.

18 'Hydraulic Henderson', The Telegraph (Brisbane), 17 April 1888, 4.

19 For biographical details, see Raymond Whitmore, Hydraulic Henderson: Water Resources Pioneer (Brisbane: Engineers Australia, 2009); John Baillie Henderson, 'Men of the Time', in Pugh's Almanac Directory and Gazetteer (Brisbane: Theophills P. Pugh, 1902), 441; Obituary in The Week, 18 February 1921, 13; 'The Sketcher Men of Mark', The Queenslander, 31 July 1897, 221; R. L. Whitmore, Eminent Queensland Engineers (Brisbane: Institution of Engineers, 1984); H. J. Gibbney, 'Henderson, John Baillie (1936-1921)', in Australian Dictionary of Biography (1972), adb.anu.edu.au/biography/henderson-john-baillie-3751/text5909, accessed 31 August 2016. 
future' ${ }^{20}$ He proposed that the government could undertake 'some comprehensive scheme of protection' on the 'betterment' principle, clearly linking state-building with technology. ${ }^{21}$ As a government employee, Henderson was obliged to fulfil state imperatives, such as the provision of town, artesian and stock route water supplies; irrigation infrastructure; and, in this case, the conservation of potable water and the mitigation of floods in south-east Queensland.

Yet to read Henderson as simply a servant of the state, entirely focused on colonial imperatives of progress, denies the complexities of settler relationships with a new environment. Henderson challenged the orthodox hydrology of his day, departing from his engineering predecessors. Just as the meteorologists Henry Russell in New South Wales (NSW) and Queensland's Clement Wragge resisted wider meteorological efforts to devise large-scale theories of climatic cycles and standardisation of data collection, so too did Henderson undertake a more independent approach. For instance, he rejected the notions of universal laws of hydrology and the unquestioning transplantation of intercolonial models and precedents throughout the empire, realising the complexities of local environments. ${ }^{22}$ He recognised the 'highest importance' of 'accurate knowledge' of local variation in rainfall, evaporation and flood behaviour, and advocated the improvement of local hydrological data and understanding through observation, field work, experiments and meticulous record-keeping. ${ }^{23}$

Although a loyal public servant, mindful of his superiors and anxious not to 'trench upon policy' in his reports, Henderson departed from mainstream technocratic solutions and advocated flood warning systems, water meters, public education and the prevention of building on the floodplain..$^{24}$ Motivated in part by recognition of the cost and time required to build engineering works, these alternative approaches anticipated twentieth-century, non-structural approaches to water security and flood mitigation. ${ }^{25}$ Henderson added an awareness of the human-created flood hazard to settler understandings of floods at the end of the nineteenth century.

20 J. B. Henderson, 'Floods in the Brisbane River, and Schemes for Abatement of their Disastrous Effects', Queensland Votes and Proceedings (QVP) (1896) 4: 295, 300.

21 Henderson, 'Floods in the Brisbane River', 295.

22 B. L. Finlayson and T. A. McMahon, 'Australia v. the World: A Comparative Analysis of Streamflow Characteristics', in Fluvial Geomorphology of Australia, ed. Robin F. Warner (Sydney: Academic Press, 1988), 17; O'Gorman, 'Colonial Meteorologists and Australia's Variable Weather', 87.

23 Henderson, 'Floods in the Brisbane River', 296; 'Water experiments', The Telegraph, 16 August 1890, 2.

24 J. B. Henderson, 'Annual Report of the Hydraulic Engineer on Water Supply', QVP (1894), 3: 1455, Appendix 6; J. B. Henderson, 'Floods and the Mitigation of evil effects', QVP (1895), 3: 989-91; Henderson, 'Floods in the Brisbane River', 12-13.

25 John Handmer and Stephen Dovers, Handbook of Disaster and Emergency Policies and Institutions (London: Earthscan, 2007); David Ingle Smith, 'Urban Flooding in Queensland-A Review' (Canberra: Centre for Resource and Environmental Studies The Australian National University, 1998), prepared for the Department of Natural Resources, Queensland; 'Caroline Wenger, Karen Hussey and Jamie Pittock, Living with Floods: Key Lessons from Australia and abroad (Gold Coast: Queensland National Climate Change Adaptation Research Facility, 2013). 
Clear commonalities between meteorology and hydrology existed in the Australian colonies. Such an overlap was even more evident in Queensland when the Meteorological Bureau was transferred to the Water Supply Department under Henderson's control in 1903. Both disciplines brought with them Eurocentric scientific knowledge and training, but, impeded by deficiencies in local data, were forced to rely on amateur records and settler memories of climate and flooding events. ${ }^{26}$ Henderson faced a greater obstacle than his counterparts in the southern colonies of NSW and Victoria, as he had less than 20 years of recorded local data on which to draw.

Over the course of the nineteenth century, the scientific discipline of hydrology in the Australian colonies became entwined in the broader goal of socioeconomic progress. On the eve of Federation in 1901, meteorologists regarded their discipline as a 'nation building scientific tool'. ${ }^{27}$ Similarly, scientists contended that an understanding of hydrology might offer pastoralists and farmers some security against the vagaries of drought and floods, which would later be understood as the result of the El Niño-Southern Oscillation. Henderson clearly appreciated this link between development and hydrology, declaring in 1910, 'It is impossible to overestimate the great value of this work and what a sound knowledge of the seasons means in connection with the prosperity of this State'. ${ }^{28}$ As Henderson produced maps, hydrological graphs and tables for distribution to both the government and to landholders, he began to codify the local weather and hydrology. In doing so, he played a key role in reducing the complexity of natural systems to simple schematic representations, creating modern tools of the twentieth-century state. ${ }^{29}$

In this approach, Henderson was following the norms of his profession. His reports, for instance, reveal a close association with colleagues and vast reading of contemporary engineering studies both from Australasia and further afield. He maintained an extensive private library, stocked with technical journals and bulletins from Australia, Britain and the United States. His membership of civil engineering associations across three continents increased his access to current information. ${ }^{30}$ His insatiable reading was poetically acknowledged in the Queenslander, which described him in 1897 as having 'no hobbies except his library; a regular gormandiser [sic] for literature. ${ }^{31}$

26 O'Gorman, “'Soothsaying” or Science', 179

27 Douglas, “"Under such sunny skies”, 10.

28 'Annual Report of Hydraulic Engineer on Water Supply', Queensland Parliamentary Papers (QPP) (1910), 3 : 875.

29 Scott, Seeing Like a State; Douglas, "“Under such sunny skies”, 4.

30 Whitmore, Hydraulic Henderson, 139.

31 'Men of Mark', The Queenslander, 31 July 1897, 221. 
For all his reading, Henderson did not produce scientific papers, limiting his publications to government reports and official correspondence. But Henderson saw his work as contributing to a growing data-dependent international science, acknowledging in his Annual Report for 1910 that his department's compilation and tabulation of climatological records had importance for both scientists and 'the lay mind'. His work, he maintained, would create environmental knowledge that would enable settlers to 'acquaint ourselves, as well as our neighbours in the other States and people in parts beyond the seas', while correcting 'erroneous impressions' of local conditions. ${ }^{32}$ The utilitarian purpose of his science remained at the forefront of his work, as he endeavoured to produce data in a form:

that may be readily consulted and understood by farmers, pastoralists and others already on the land, as well as by those wishing to settle thereon, and in no less a degree should it be valuable to bankers, doctors and the general public. ${ }^{33}$

Science, local concerns and national imperatives were inseparable in the case of government hydraulic engineering and meteorology.

With the education of the local citizenry in mind, Henderson requested his annual reports be 'widely distributed among the people interested in the matter' and his instructions on flood warnings be 'published in a condensed form' for wide circulation. ${ }^{34}$ Henderson believed in the importance of public education, acknowledging the 'great assistance' the press could play in enhancing lay understandings of the local environment, while reinforcing his authority in matters hydrological. ${ }^{35}$ Newspapers throughout Queensland quoted his reports extensively, with the Telegraph describing his work as of 'great magnitude and importance'. ${ }^{36}$ In addition to citing his reports, the press regularly reported on Henderson's activities, sought his opinion on water matters and published letters in response to his findings. ${ }^{37}$ This commentary prompted public discussion on hydraulic matters and added to settler understandings of local environmental conditions.

With regard to government involvement in the formal acquisition of environmental knowledge, Queensland's bureaucracy entered the field of hydraulic engineering later than its southern counterparts. This was a handicap Henderson frequently bemoaned. Until his promotion to Hydraulic Engineer in 1883, Queensland depended on

\footnotetext{
32 'Annual Report of Hydraulic Engineer on Water Supply', QPP (1910), 3: 876.

33 'Annual Report of Hydraulic Engineer on Water Supply', 876.

34 J. B. Henderson to the Under Secretary, Treasury, 5 December 1894. Letter 6165. Item ID 950329.

Queensland State Archives, Runcorn.

35 Henderson, 'Floods in the Brisbane River', 298.

36 'Brisbane Water Shed', The Telegraph, 18 January 1894, 4. Other examples of publication of Henderson's reports include 'Abatement of the Disastrous Effects of Future Floods', Queensland Times, 21 July 1896, 6; 'Flood Warnings', The Telegraph, 13 January 1896, 2; 'Flood Prevention', Brisbane Courier, 20 June 1896, 9.

37 'The Weather', The Telegraph, 11 January 1898, 2; 'Flood Prevention', Brisbane Courier, 26 June 1896, 7; 'Flood Prevention', Brisbane Courier, 17 January 1898, 6.
} 
consultant engineers from Victoria to address its water-supply challenges. Engineers such as Thomas Oldham and Joseph Brady, fresh from their Victorian experiences, were contracted to design Brisbane dams. This practice presented another problem as not only did they transplant their British training and hydrological formulae, they brought with them their knowledge of southern Australian rainfall, run-off and dam yield, with little realisation of regional difference in a vast continent that ranged from temperate to tropical climates. Brisbane's new but inadequate dams were the result of a failed appreciation of local climatic variation. Faced with the problem of an insufficient water supply for the ever-growing economy, Queensland's colonial government commissioned Henderson to investigate. His 1880 report offers an insight into contemporary hydrological knowledge, just as Charles Todd's paper on the history of Australian meteorology later did for that science in $1893 .{ }^{38}$ Henderson's tabulation of rainfall, recording of known droughts and floods since colonisation and his estimates of local evaporation and stream flow provide some of the earliest examples of a systematic settler analysis of the colonial environment.

\section{Understanding the local environment}

Australian rivers, with their extreme high annual variability in discharge, are vastly different from European rivers. In fact, with southern Africa, Australia has the most variable annual river flows in the world. In geomorphological terms, they are 'nonequilibrium' rivers, stable for only relatively short periods of time. ${ }^{39}$ This extreme variability of river flow is a result of Queensland's climate. The state's weather is greatly influenced in the longer term by variations in the Southern Oscillation Index and infrequent short-term events, including cyclones, which can dramatically affect local rivers. For instance, the $309 \mathrm{~km}$ Brisbane River has a flow regime that is highly variable even by Australian standards. Streamflow records prior to 1959 (after which the Somerset Dam affected the natural flow regime) indicate that, for some periods, there was no river discharge in Brisbane. By contrast, during an 1893 flood, the Brisbane River flowed at an estimated $13,700 \mathrm{~m}^{3}$ of water per second, such was the volatility of local hydrological regimes. ${ }^{40}$

\footnotetext{
38 J. B. Henderson, 'Report on Brisbane Water Supply', QVP (1880), 2: 1171-200a; Charles Todd, 'Meteorological Work in Australia: A Review', in Report of the Fifth Meeting of the Australasian Association for the Advancement of Science (Adelaide: The Association, 1893).

39 Finlayson and McMahon, 'Australia v. the World: A Comparative Analysis of Streamflow Characteristics', 35; Karskens, 'Floods and Flood-mindedness', 319.

40 J. Kemp, J. M. Olley, T. Ellison and J. McMahon, 'River response to European Settlement in the subtropical Brisbane River, Australia', Anthropocene 11 (2015): 50, doi.org/0.1016/j.ancene.2015.11.006. The years 1841, 1844, 1893 and 1974 experienced peak discharges over 10,000 $\mathrm{m}^{3}$ per second. WMA Water, 'Brisbane River 2011 Flood event-flood frequency analysis', 'Report for Queensland Floods Commission of Inquiry' (2011), 30. Mark Babister, 'Report to the Queensland Flood Commission of Inquiry: Final Report, May 2011', protect-au.mimecast. com/s/nbpzB5SK40AbS7?domain=floodcommission.qld.gov.au, accessed 16 October 2017.
} 
Settler knowledge of this volatility was only gleaned after decades of record-keeping and scientific analysis. But what knowledge did the colonists have of Australian rivers when they arrived in Brisbane in the 1820s? Flood records began at Windsor (NSW) as early as 1799 , and by the 1850 s there were official reports and newspaper accounts of floods. A weather station opened at Goulburn (NSW) in 1858, with others opening along the Hawkesbury-Nepean Rivers and their tributaries after the 1860s, providing Australia's longest flood history record ${ }^{41}$ In the NepeanHawkesbury catchment, floods were common and often large, with nine floods between 1775 and 1821 reaching between $12 \mathrm{~m}$ and $14.6 \mathrm{~m} .{ }^{42}$ Settlers were familiar with floods on the giant inland Murray-Darling system, with a flood on the Murray River in 1852 reaching $12.34 \mathrm{~m}$ at Gundagai (NSW), which forced the town's relocation. ${ }^{43}$ Meanwhile, in low-lying Brisbane, nine substantial floods were recorded between 1841 and 1870 (Table 1). Conversely, Brisbane experienced extremely dry years in 1864-66 and 1876-78 and, with a population of 30,000 in 1879 , concerns grew about providing a reliable water supply. ${ }^{44}$ The colonial government required a suitable engineer to address the issue, and employed John Baillie Henderson as a consultant.

Table 1: Recorded flood heights in Brisbane up to 1880, measured at the Port Office Gauge using the Australian Height Datum (AHD)

\begin{tabular}{|l|l|}
\hline Year & Flood height in metres AHD \\
\hline 1841 & 8.43 \\
\hline 1843 & 2.76 \\
\hline 1844 & 7.03 \\
\hline 1852 & 2.91 \\
\hline 1857 & 3.27 \\
\hline 1863 & 3.32 \\
\hline 1864 & 3.78 \\
\hline 1867 & 2.46 \\
\hline 1870 & 2.89 \\
\hline
\end{tabular}

Source: Brisbane River Flood Hydrology Models, Main Report (Brisbane: Department of Natural Resources, 2013), 35.

Henderson moved from Townsville to Brisbane, charged with the challenging brief of finding the 'best means' to provide the city with a water supply adequate for a population of at least 100,000 people. The existing Enoggera Dam, designed for that purpose in 1864 , had proven insufficient. This dam had been

41 Karskens, 'Floods and Flood-mindedness', 325.

42 Karskens, 'Floods and Flood-mindedness', 327.

43 O'Gorman, Flood Country, 15-29.

44 Henderson, 'Report on Brisbane Water Supply', 1172, Pugh's Almanac, Directory and Gazetteer (Brisbane: Theophilus P. Pugh, 1881), 84. 
designed by Oldham, an Irish-born civil engineer with experience working on Melbourne's Yan Yean scheme, which was the first Australian municipal scheme to use a dam for urban water supply. In Queensland, Oldham applied his British training and Victorian experience and, using a limited official rainfall record (1860-64), calculated an average annual rainfall of 46 inches $(1,168 \mathrm{~mm})$. Using a formula developed for English conditions, Oldham debited one-third of the rainfall to account for evaporation loss and absorption, implying a yield of twothirds for the dam. ${ }^{45}$

Political infighting prompted Oldham's replacement by the engineer Brady in 1864, before the dam was constructed. After gaining railway experience in Ireland and Victoria, Brady had also worked on Victoria's Yan Yean scheme, in addition to the Bendigo waterworks and Coliban River water supply. His Brisbane calculations were based on six years of rainfall records, but with the Brisbane River watershed 'not yet surveyed' and without any catchment-wide rainfall data upon which to draw, he assumed the watershed rainfall 'was probably much greater'. Brady estimated a loss of 66 per cent from 'evaporation, percolation and overflow in floods', ${ }^{46}$ almost half Oldham's yield calculations. Oldham and Brady, familiar with Britain's and Victoria's temperate climate and rainfall patterns, had little sense of how subtropical Brisbane might differ.

Henderson's 'Report on Brisbane Water Supply' in 1880 offered a compendium of contemporary hydrological knowledge, including international data. Given the inadequate hydrological data available, his report and recommendations were brave. ${ }^{47}$ With the city's population approaching 37,000 by this time, Henderson compared Brisbane's average water consumption figures with cities of a similar size in the United Kingdom, Europe, the United States and Australia. He regarded an annual consumption in Brisbane of 40 gallons $(181 \mathrm{~L})$ per person per day to be 'ample for all purposes' in a 'semi-tropical' climate. This figure was some 20 gallons $(90 \mathrm{~L})$ less than was used each day in Melbourne. The lower Brisbane quota reflected Henderson's view that water usage in the southern colony was wasteful. Accordingly, he also recommended Brisbane minimise such profligate water use by introducing domestic and other water meters as had been used in Boston since 1861. ${ }^{48}$

45 Geoffrey Cossins, 'Early Hydrology of the Brisbane Area', Engineering Update (Brisbane) 5, no. 1 (1997): 18; Henderson, 'Report on Brisbane Water Supply', 1176.

46 Joseph Brady, 'Paper Descriptive of the Water Supply to the City of Brisbane, Queensland, 1866: Together with the General Plan and Section' (Brisbane, 1866). Item ID 664671. Queensland State Archives, Runcorn.

47 Joseph Powell, Plains of Promise Rivers of Destiny: Water Management and the Development of Queensland 1824-1990 (Brisbane: Boolarong Publications, 1991), 34; Henderson, 'Report on Brisbane Water Supply'.

48 Henderson, 'Report on Brisbane Water Supply', 1200. 
According to Henderson, the 'accurate knowledge' of the quantity of rainfall and its 'seasonable distribution is of the highest importance to the engineer entrusted with the design of water storage and drainage works. ${ }^{49}$ The annual water yield for any dam design requires local data to determine both the rainfall/run-off ratio and evaporation ratios. Henderson understood this and made it his goal to understand the local climatic conditions. Such accurate accounting of river catchment rainfall, run-off and evaporation was his most urgent task. Applying international and Victorian knowledge to the job, Henderson undertook the first detailed hydrological analysis of the Enoggera Dam and Brisbane's water supply. He rejected the notion of applying international and intercolonial formulae, noting the enormous variations in the hydrological data. For example, evaporation ratios, a component of the yield, ranged from one-sixth in Bombay to one-third in the Coliban Scheme, Victoria.

Ignoring Indigenous knowledge, Henderson used Brisbane rain gauge data and Enoggera records to compile a rainfall map for Brisbane dating back to 1860. In his analysis of the existing colonial records, Henderson criticised their accuracy. For example, he cited previous Enoggera recordings collected from a house roof gauge, $5.2 \mathrm{~m}$ above the ground and $85 \mathrm{~m}$ above sea level—both factors known to diminish the accuracy of the readings by approximately 10 per cent. At Enoggera, he found high rainfall variability with a range of 2,417 $\mathrm{mm}$ (1870) to just $597 \mathrm{~mm}(1877) . .^{50}$ Drawing on these results, Henderson estimated the yield of the Enoggera Dam to be one-twelfth of the rainfall over the total catchment in a drought periodsignificantly less than both Oldham and Brady had calculated.

Victorian records accumulated since the opening of the Yan Yean scheme in 1857 were also insufficient to challenge British notions of hydrology in an Australian climate. Using models from evaporation tests from Sydney, Melbourne and Bombay, Henderson conducted experiments at his private residence that led him to revise the annual evaporation rates for Brisbane. ${ }^{51}$ Realising the limitations of his small evaporimeter, Henderson adopted a somewhat high value of 43.3 inches $(1,102 \mathrm{~mm})$ per annum, based on Victorian data from a large buried tank..$^{52}$

Charged with finding locations for future water storage, Henderson then used his new yield formula, derived from the Enoggera Dam analyses and his own experiments, to assess the various proposed dam sites. He struggled to determine if the rainfall at these places would adequately supply the required yield, a 'problem of easy solution' when engineers are 'possessed of accurate and reliable information respecting the various conditions of rainfall and discharge of the streams'. In Brisbane, however,

49 J. B. Henderson, 'Floods in Brisbane River, and Schemes for Abatement of their Disastrous Effects', QVP (1897), 3: 298.

50 Henderson, 'Report on Brisbane Water Supply', 1172. Measurements have been converted from imperial.

51 'Water Experiments', The Telegraph, 16 August 1890, 2.

52 Henderson, 'Report on Brisbane Water Supply', 1177; Cossins, 'Early Hydrology of the Brisbane Area', 20. 
he found such data 'altogether unobtainable' and 'in consequence I candidly confess my inability to answer this question with satisfaction to myself'. Concerned at the 'paucity and poor quality of the data on rainfall, evaporation and river runoff, he had to rely on the irregular records available. ${ }^{53}$

To Henderson's lament, Queensland's data collection proceeded at a much slower pace than in the southern colonies. Continuous rainfall records had been kept throughout Australia-Adelaide since 1839, Melbourne 1853, Sydney 1858, Perth 1860 and Tasmania 1880 - with earlier, irregular records kept in many cases. ${ }^{54}$ In 1870, the entire Queensland colony had only 36 registered rainfall stations, with 422 by 1880 and over 600 in 1900, but most were concentrated in the south-east corner of the state. In comparison, when Queensland had 400 stations, Victoria, a much smaller state, had over 450 , and 15 years of rainfall data. ${ }^{55}$ Queensland hydrologists were hamstrung by a lack of settler local knowledge, and Henderson stressed the need to establish systems to record rainfall and river data. He realised what the historian Livingstone observes: 'local conditions pose local problems needing local solutions ${ }^{56} \mathrm{Hydraulic}$ engineering had to respond to the environment.

Henderson found an intellectual ally in Clement Wragge, Government Meteorologist after 1887. Passionate about his work, the populist Wragge produced meteorological data in regular self-published journals and gazettes. Like Henderson, Wragge believed that meteorology should be dedicated to understanding the 'peculiarities of local climate', which brought him into direct conflict with his colonial contemporaries who sought to locate continent-wide trends. Wragge insisted on a 'rigidly scientific system', based on field observation and data collection, rather than the more theoretical analyses of other meteorologists. ${ }^{57}$ By 1893 , he had established 16 firstorder, 36 second-order and 34 third-order meteorological stations in Queensland, and 398 rain stations. ${ }^{58}$ After Wragge's dismissal in 1902, the state's weather bureau was subsumed into the Water Supply Department. Initially the government intended to collect only rainfall records, but Henderson fought against this, arguing that 'a break in the records' would be 'a public calamity, and moreover, would greatly diminish the scientific value' of both past and future records. ${ }^{59}$ Henderson prevailed, and the department continued to collect data and maintain an unbroken series of climatological observations, finally bringing Queensland into line nationally. Now responsible for meteorology, Henderson used rainfall data to prepare graphs of annual, monthly and mean rainfall in Brisbane, a first in Queensland. Drawing

53 Whitmore, Hydraulic Henderson, 28; Henderson, 'Report on Brisbane Water Supply', 1176.

54 Douglas, 'Under such sunny skies', 22.

55 Powell, Plains of Promise, 40.

56 Livingstone, Putting Science in its Place, 45.

57 O'Gorman, 'Colonial Meteorologists and Australia's Variable Weather', 79-81.

58 Powell, Plains of Promise, 89.

59 'Annual Report of the Hydraulic Engineer', QPP (1903), 3: 797. 
on French calculations, he also introduced flood modelling in the state. ${ }^{60}$ Through these actions, Henderson created considerable hydrological and environmental knowledge, improving settlers' understanding of the local hydrological system. ${ }^{61}$

A further imperative provided a stimulus for Henderson's research. In the 1880s, the colonial government demanded the development of irrigation as a means of opening up the country for closer settlement. The government commissioned the irrigation engineers Arthur Rigby and William McKinnon to investigate potential irrigation areas, but, like Henderson, they were handicapped by insufficient records. They advocated accurate river gauging, contour maps, rainfall data and comprehensive hydrological surveys, but their pleas fell on deaf ears. Like rainfall measurement, stream gauging in Queensland had fallen far behind its southern counterparts, having been undertaken in Victoria since 1865. Both Victoria and NSW employed regular stream-gauging staff after 1890. Despite Henderson's continued requests since the 1880s, the Queensland Government did not employ a stream gauger until 1909, which might have been the result of scarce financial resources and a small population in a vast state.

Henderson exploited the government's desire for irrigation to achieve his ends to enhance the colony's hydrological knowledge. He argued that streams required for irrigation must 'be continuously measured in a proper manner'. ${ }^{62}$ Finally, the government relented, as insufficient data was hampering decisions about water allocations for irrigation. As this example suggests, it was not the desire for environmental knowledge for its own sake that motivated the government's change of heart. Instead, it was a product of the confluence of science and the aims of the state, with research directed by socioeconomic objectives. ${ }^{63}$

Consequently, under the Queensland Rights in Water and Water Conservation and Utilization Act 1910, the state government established 14 gauges on 13 streams, read by local voluntary gauge readers, and increased the number to 50 by 1920 . Between 1909 and 1919, 784 measurements were taken, but most were concentrated in the more populous south-east corner of the state. ${ }^{64}$ The resultant data continue to inform flood modelling and flow rate calculations for the Brisbane River in the twenty-first century.

60 Examples of Henderson's early flood modelling appear as appendices in Henderson, 'Floods in Brisbane River'; Cossins, 'Early Hydrology of the Brisbane Area', 21.

61 Powell, Plains of Promise, 88.

62 'Annual Report of the Hydraulic Engineer', QVP (1901), 3: 1303.

63 Robin, How a Continent Created a Nation, 202. The link between state and science has also been made in the case of drought in Ruth Morgan, Running Out?: Water in Western Australia (Crawley, WA: UWA Publishing, 2014), 44.

64 H. Eklund, 'Irrigation Activities 1919-20', Water Supply Department Queensland Bulletin 1 (1920): 4. 
In both hydrology and meteorology, professional needs prompted the recording of rainfall, run-off and streamflow behaviour. According to the historical geographer Joseph Powell, however, Queensland engineers surpassed meteorologists in gathering such data and, in doing so, 'steadily advanced the common stock of environmental information' ${ }^{65}$ I contend that Henderson exhibited a genuine thirst for hydrological knowledge. He may have been driven by the passion of scientific pursuit, a desire to understand the environment or to serve his employer and its goals for development. Alternatively, he may have been motivated by a desire to 'know thine enemy'-in this case, nature-in order to control it. Whatever the reason, Henderson maintained his adherence to the importance of stream gauging and rainfall monitoring until the end of his long career.

\section{Assessing subtropical floods}

In addition to his collection of rainfall and streamflow data, Henderson undertook significant research on flooding, which contributed substantially to settler understandings of the Queensland environment. Two of the largest floods recorded in Brisbane's history occurred in February $1893(8.35 \mathrm{~m}$ and $8.09 \mathrm{~m}$ AHD at the Port Office Gauge), with a smaller flood occurring in between these events. ${ }^{66}$ As the floodwaters receded, locals called on the government to prevent future flooding. Such a response suggests that flooding in late nineteenth-century Queensland was a 'problem of water control', one that could be solved by engineers and engineering works. ${ }^{67}$

In Queensland, the government looked to its own Hydraulic Engineer, Henderson, to investigate the causes and extent of the floods and to consider measures 'that might be taken for controlling floods or for mitigating their serious effects' ${ }^{68}$ Henderson drew on his extensive knowledge of flood mitigation, gleaned from his wide reading of an international engineering literature. But Henderson, no deskbound engineer, accompanied his reading with practical research. He visited flooded areas to investigate, just as he had covered 10,000 miles in western Queensland in

65 Joseph Powell, 'Snakes and Canons: Water Management and the Geographical Imagination in Australia', in Environmental History and Policy: Still Settling Australia, ed. Stephen Dovers (Melbourne: Oxford University Press, 2000), 59.

66 Brisbane River Flood Hydrology Models, Main Report (Brisbane: Department of Natural Resources, 2013), 36. In 1971, Geoscience Australia assigned the mean sea level for $1966-68$ a value of $0.00 \mathrm{~mm}$ on the Australian Height Datum.

67 Handmer and Dovers, Handbook of Disaster and Emergency Policies and Institutions, 11, 85; Wenger, Hussey and Pittock, Living with Floods, vii.

68 J. B. Henderson, 'Floods, Brisbane and Mary Rivers', in 'Annual Report of the Hydraulic Engineer', QVP (1894), 3: 1469. 
1884 during a four-month study of potential sites for water storage. ${ }^{69}$ Days of field observations in boats, observing and sketching, and visiting NSW and Victorian flood mitigation works, also informed his conclusions. ${ }^{70}$

In his 1895 interim report on the 1893 floods, 'Floods, and the Mitigation of their Evil Effects', Henderson made several recommendations based on international examples. He recommended a cheap system of timely flood warnings as used in France, and a system of stream gauges, with an accompanying bevy of local unofficial and official gauge readers, based on an American model. These readers would telegraph the results to both local and central telegraph offices. To cope with floods and facilitate this warning system, Henderson recommended telegraph lines be raised. ${ }^{71} \mathrm{He}$ embarked on a program of flood modelling of Queensland rivers using the few stream gauges available. Cross-sections of rivers were drawn and graphs and tables were prepared after 1895 using catchment rainfall to model floods in the area of the Brisbane, Mary, Burnett, Condamine, Severn, McIntyre and Fitzroy rivers. These sophisticated studies provided a significant advancement of Queensland's hydrological and environmental knowledge. ${ }^{72}$

What is of interest in Henderson's final flood report in 1896 is the dearth of flood knowledge at the time. Henderson prepared a flood diagram, which he claimed to be 'the first compilation of the kind'- the earliest known flood history for south-east Queensland. His report dismissed Indigenous flood knowledge in a single phrase, declaring the 1893 floods 'to be without parallel in the history of Queensland as far as can be determined by authentic and recorded observations', drawing only on records since British exploration in the 1820s. ${ }^{73}$ He noted that he expended 'much time and trouble' to locate the data, having to draw on settler accounts rather than scientific records. Among them were the recollections of the journalists J. J. Knight and Archibald Meston, author and merchant Nehemiah Bartley and Royal Society of Queensland member Elizabeth Coxen. ${ }^{74}$ Just as Russell relied on settlers' weather descriptions owing to a lack of data, so did Henderson-he had no choice. ${ }^{75}$ As Henderson noted, the recording of rainfall in the Brisbane River basin had been 'sadly neglected until four or five years ago'. Using any available records, he compiled a rainfall table for the basin from 1870 (Figure 3), which he also considered to be 'the first that has been made', a claim yet to be disproven. ${ }^{76}$

69 'Report from the Hydraulic Engineer on his western journey over the Hughenden and Cloncurry Road 1886', QVP (1886), 3: 711-13.

70 'Abatement of the Disastrous Effects of Future Floods', Queensland Times, 21 July 1896, 6; J. B. Henderson to the Treasurer, 'Visit to New South Wales and Victoria', 10 July 1895, Letter 3143. Item ID 950330. Queensland State Archives, Runcorn.

71 J. B. Henderson, 'Floods, and the Mitigation of their evil effects', in 'Annual Report of the Hydraulic Engineers', QVP (1895), 3: 989.

72 Whitmore, Hydraulic Henderson, 123; 'Floods in the Brisbane', Queensland Times, 4 December 1894, 6.

73 Henderson, 'Floods in Brisbane River', 295.

74 Henderson, 'Floods in Brisbane River', 295.

75 O'Gorman, “'Soothsaying” or Science', 178, 184-5.

76 Henderson, 'Floods in Brisbane River', 297. 
Table B.

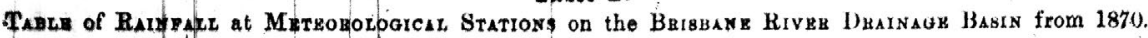

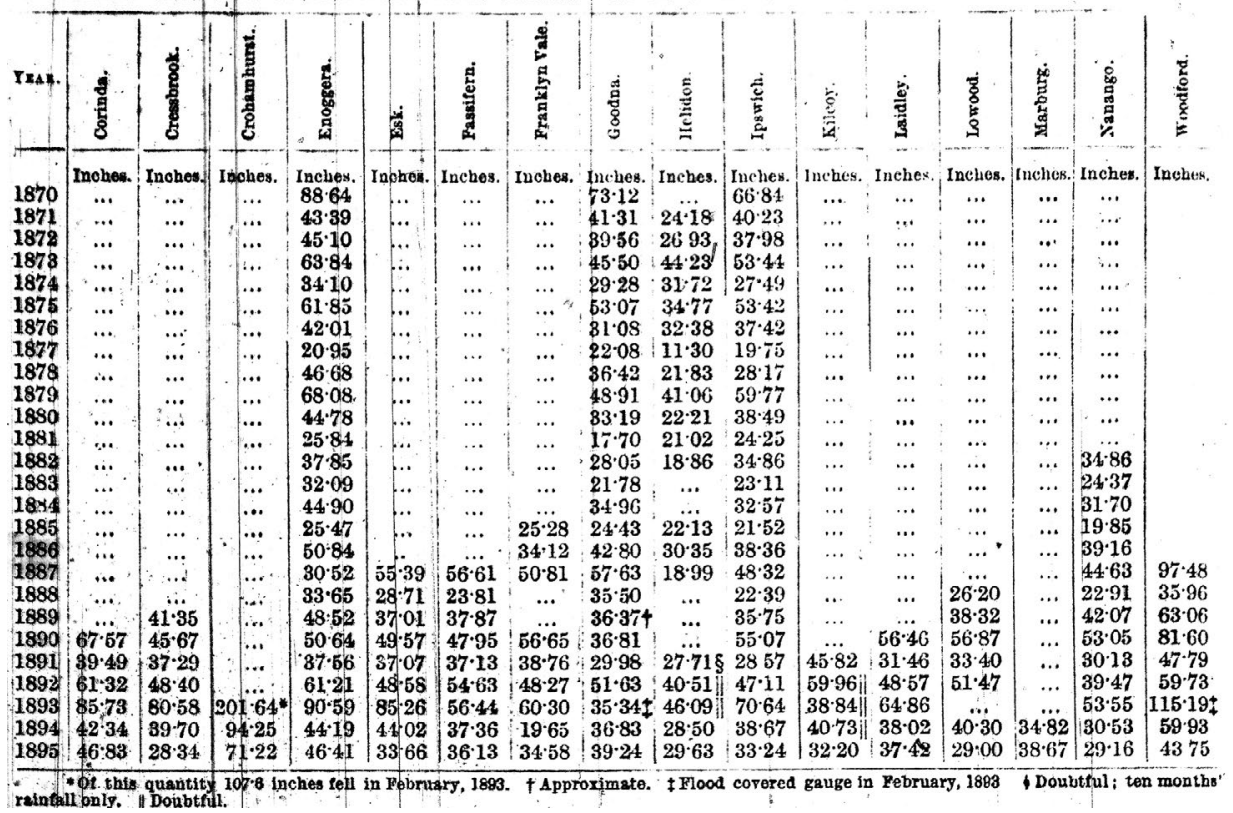

Figure 3: Henderson's table for rainfall at meteorological stations in the Brisbane River catchment from 1870

Source: 'Floods in Brisbane River, and Schemes for Abatement of their Disastrous Effects', Queensland Votes and Proceedings 4 (1896), 308.

Having painstakingly collected these data, Henderson was keen to disseminate it and recruit local help. He encouraged settlers to educate themselves, distributing stream-gauging diagrams on which local residents could record their own stream height data. He recruited 'observers' (local residents or often police officers) and his own staff throughout Queensland to measure streams, record rainfall and log weather conditions in accordance with standardised instructions (Figure 4), preparing baseline data never before collected by the colonial government. ${ }^{77}$ Every flood, Henderson maintained, would 'present opportunities for collecting valuable data', and augment existing knowledge. ${ }^{78}$ While voluntary labour extended his resources in a vast colony, it also engaged local amateurs in data collection. This practice points to a long tradition, noted by Robin, of the interdependence of government, science and the public. ${ }^{79}$ As Henderson met with local councils and chambers of commerce and addressed public meetings, these discussions further communicated and shaped his hydrological science. ${ }^{80} \mathrm{He}$ produced a map of areas flooded in

77 J. B. Henderson, 'Flood Warnings Memorandum from Water Supply Department', QPP (1897), 4: 642.

78 J. B. Henderson, 'Annual Report of the Hydraulic Engineer on Water Supply', QVP (1896), 4: 426.

79 Libby Robin, Defending the Little Desert: The Rise of Ecological Consciousness in Australia (Melbourne: Melbourne University Press, 1998), 4.

80 'Waterworks Report', Darling Downs Gazette, 13 March 1897, 4; 'General Summary', Darling Downs Gazette, 30 January 1897, 'Ipswich', Brisbane Courier, 17 May 1892, 5; 'Wallumbilla Whiffs', Western Star and Roma Advertiser, 20 April 1895, 3. 
February 1893 to be distributed by the police to residents and businesses likely to be flooded in future. Maps and rainfall diagrams were, according to Henderson, 'eagerly sought after', which proved, he contended, the public's appreciation for such information. ${ }^{81}$ The Brisbane Telegraph acknowledged the contribution to scientific thought, declaring his rainfall diagrams 'exceedingly interesting and valuable' and 'one of the most valuable diagrams in existence'. ${ }^{82}$

\section{A.}

FLOOD WARNINGS.

BRISBANE AND STANLEY RIVERS.

When heavy rain is falling or has fallen on the drainage areas of the Brisbane or Stanley Rivers or their main tributaries, and when there is the least chance or sign of a flood in those streams, telegrams are required as follows from the undermentioned stations:-

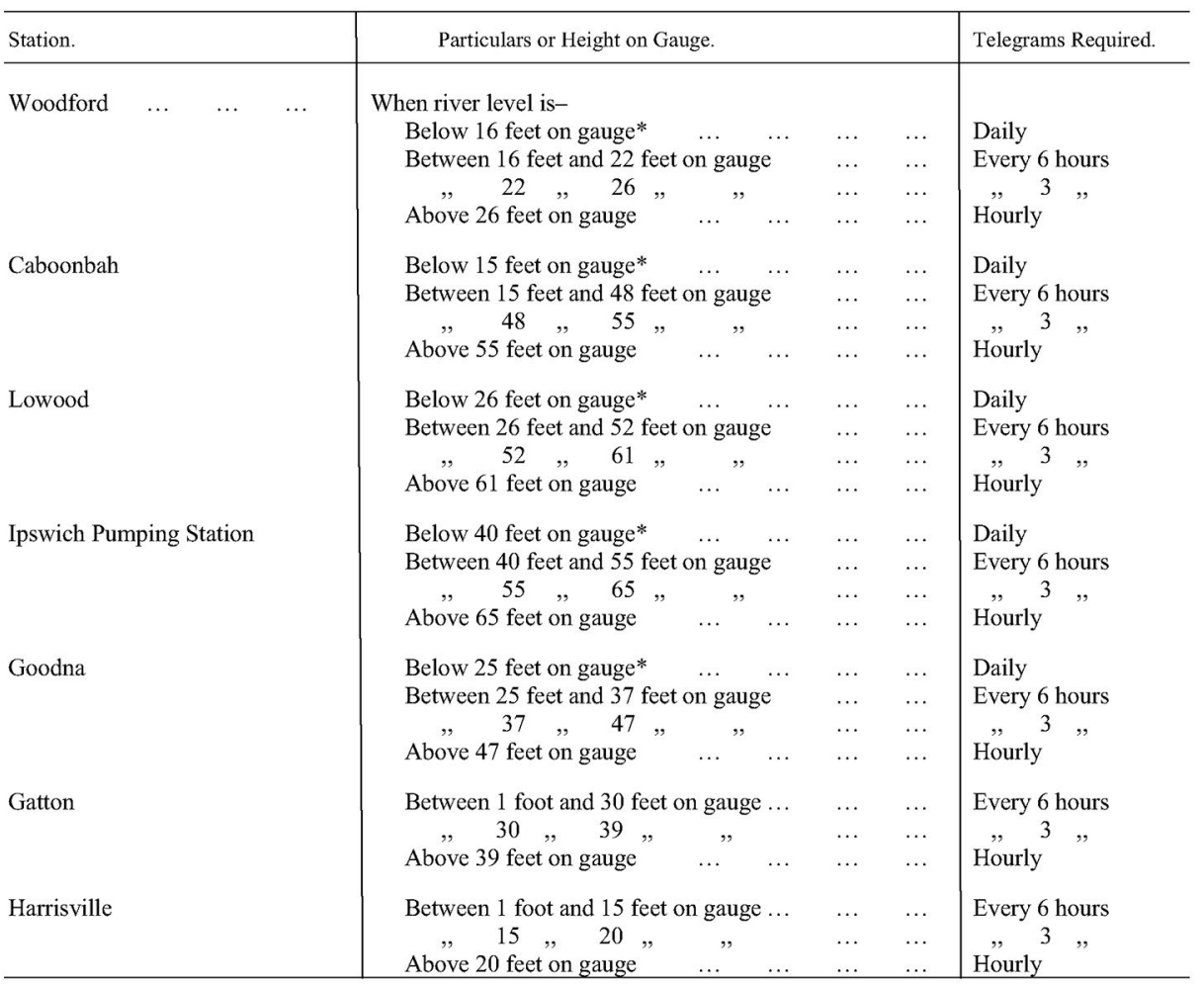

* From these gauges only during January, February, March, April, May, and June

Brisbane, January, 1896.

\section{Figure 4: Standardised instructions issued to stream 'observers' by Henderson} in 1897

Source: J. B. Henderson, 'Flood Warnings', Queensland Votes and Proceedings 4 (1897), 642.

81 J. B. Henderson, 'Annual Report of the Hydraulic Engineer on Water Supply', QVP (1894), 3: 1456.

82 'Rainfall Diagram', The Telegraph, 22 September 1890, 5; 'Hydraulic Engineers Report', The Telegraph, 27 October 1891, 4. 
In addition to raising public awareness, Henderson consulted with the commissioners of police and railways and the superintendent of the electric telegraph to devise and instigate flood warning systems and ways to mitigate flood damage. ${ }^{83}$ He undertook a tour of the NSW and Victorian flood mitigation schemes on the Richmond, Clarence, Hunter and Yarra rivers and, with his staff, conducted field work aboard boats. ${ }^{84}$ Once in control of meteorology after 1902, Henderson argued that Queensland's weather forecasts and meteorological publications should be consistent with those of the southern states and internationally. Doing so was part of a broader ambition to improve Queensland's climate knowledge. His first aim recognised the scientific opportunities offered by Federation, the unification of the six separate British colonies to form the Commonwealth of Australia in 1901, and the need to fulfil national responsibilities and objectives. His second reflected a belief in the necessity of climatic knowledge to aid settlers. ${ }^{85}$ As O'Gorman has argued, in Henderson's mind, ignorance of climate risked self-destruction and international ridicule among his professional peers. ${ }^{86}$

Henderson's desire for flood knowledge was shared by other settlers. After the Brisbane floods of 1890, J. P. Thomson, Honorary Secretary and Treasurer of the Queensland branch of the Royal Geographical Society, attempted to analyse flood velocity. He argued that as 'citizens domiciled on the margin of a tidal watercourse ... it behoves us to acquire a useful knowledge of our environment ${ }^{37}$ After the 1893 floods, Augustus Gregory, former Surveyor General, also estimated the discharge rates. ${ }^{88}$ But Henderson was the first to complete a systematic level survey upstream from Brisbane to the Stanley River junction and upstream to Woodford on the Stanley River. ${ }^{89}$ Using debris observations and available velocity measurements, Henderson calculated that the maximum rate of discharge during the 1893 flood was 24 million cubic feet $(680 \mathrm{ML})$ per minute. This rate, he noted, was equal to the ordinary discharge of the Indus River at Sukkar; nearly equal to the maximum flood discharge of the Nile at Cairo; and three times the maximum discharge of the Hunter River in NSW in the 1870 flood..$^{90}$ Using the most advanced hydrographic methods available, Henderson created a crude discharge rating curve. ${ }^{91}$

83 Letter, J. B. Henderson to the Hon. Treasurer, 26 February 1895. Item ID 950329, letter 913. Queensland State Archives, Runcorn.

84 Letter, J. B. Henderson to Hon. Treasurer, Visit to New South Wales and Victoria, 10 July 1895. Item ID 950330, letter 3143; Letter, J. B. Henderson to Hon. Treasurer, 19 February 1895. Item ID 950329, letter 781. Queensland State Archives, Runcorn

85 'Annual Report of the Hydraulic Engineer', QVP (1904-05), 2: 516; 'Annual Report of the Hydraulic Engineer', QVP (1910), 3: 875

86 O'Gorman, “'Soothsaying” or Science', 86.

87 J. P. Thomson, 'Notes on the Brisbane River Floods', Proceedings and Transcripts of the Queensland Branch of the Royal Geographical Society of Australia 5, part 3 (1889-90): 68.

88 Augustus Charles Gregory, 'Notes on the Geographical Conditions of the catchment area of the Brisbane River; the floods, and their origin', Proceedings and Transcripts of the Queensland Branch of the Royal Geographical Society of Australia 8 (1893-94): 54-8.

89 The Stanley River is a significant tributary of the Brisbane River.

90 Henderson, 'Floods in Brisbane River', 299.

91 Geoffrey Cossins, 'Ghosts of the 1893 Flood', unpublished manuscript (n.d.), 6. 
Henderson's work did not escape scrutiny. Colonel John Pennycuick, a consultant employed in 1899 by the government to review Brisbane's water supply, disputed the discharge figure as too high, based on his own Indian experience. ${ }^{92}$ However, a 1927 royal commission led by the Melbourne-based engineer Alan Gordon Gutteridge found Henderson's calculations more reliable than Pennycuick's. ${ }^{93}$ While engineering experts may now dispute the accuracy of Henderson's flood discharge rates, the significance of his scientific endeavours should not be overlooked. Not only did he provide the first detailed flood analysis in Queensland, his work continues to provide vital baseline data for twenty-first-century hydraulic engineers.

Henderson continued his hydrological work in the Brisbane River catchment, making further debris observations with his second-in-charge, Cyrus Williams, after the smaller 1896 and 1898 floods. Williams came to the job with years of experience as an engineer with Queensland's Department of Harbours and Rivers. Using the Chézy equation, a formula devised by the French hydraulic engineer Antoine de Chézy in 1775 to measure mean flow velocity, Williams confirmed Henderson's discharge calculation and the run-off ratio for the 1893 flood. Together, Henderson and Williams devised a discharge rating curve for central Brisbane, which they used to develop a flood forecasting system, another first. Although Henderson himself did not publish in journals, Williams produced a paper for the Institution of Civil Engineers in London in 1899 outlining their joint research. The publication included their hydrograph for 1898, a graph showing rate of flow (discharge) versus time past a specific point in a stream (Figure 5). ${ }^{94}$

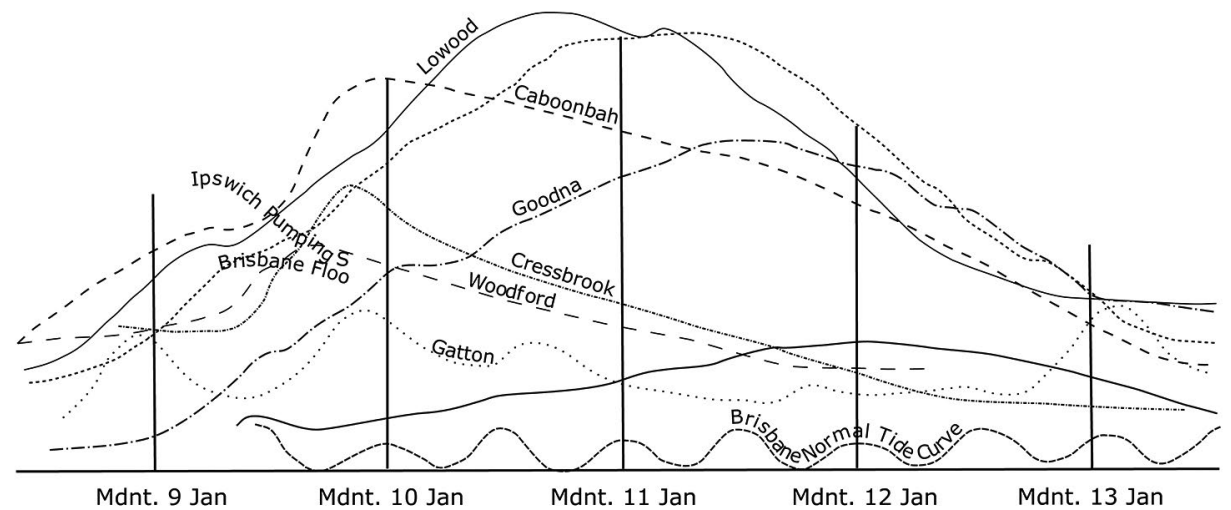

Figure 5: Redrafted from Williams' Hydrograph of Brisbane River, 1898

Source: Cyrus Williams, 'Floods in the Brisbane River; and a System of Predicting their Heights and Times', Minutes of the Proceedings of the Institution of Civil Engineers 136, (1899), 274.

92 Powell, Plains of Promise, 93; John Pennycuick, Report on Scheme for the Abatement of Floods in the Brisbane River (Brisbane: Government Printer, 1899), 3.

93 A. Gordon Gutteridge, 'Commission of Enquiry: Brisbane Water Supply Report', QPP (1928), 4: 775-854 (plus appendices).

94 Cossins, 'Early Hydrology of the Brisbane Area', 24. 
Williams recognised the scientific flaws in their research, pointing to the limited extent and longevity of the rainfall and stream gauge records. Despite the inadequate field data and erroneous hydrological assumptions, when Williams tested his system on five floods, his predicted peak varied only by inches. In the 1940s, E. M. Shepherd, Engineer for Design at the Stanley River Works Board, and charged with the hydrological studies for Somerset Dam, used an updated version of the Henderson/Williams flood forecasting model. ${ }^{95}$ Williams also published a diagram showing the flood heights above normal streamflow, detailing research undertaken with Henderson and still in use during Brisbane's 1955 flood. ${ }^{96}$

\section{Henderson's Legacy}

Despite the innovative and thorough nature of Henderson and Williams' research, their findings did not assuage state imperatives and local demands for flood control in the 1890s. The public received Henderson's interim report and government response with scathing accusations of apathy and criminal neglect, demanding 'authoritative action', not just a flood warning system. Henderson's recommendations were dismissed by the Chamber of Commerce as 'palliatives. ${ }^{97}$ In response, the government ordered further investigation to determine how definite action could be taken to minimise flooding, not just to monitor and record it. Ultimately a servant of the state, Henderson produced a comprehensive final report in 1896, 'Floods in the Brisbane River and Schemes for Abatement of their Disastrous Effects', that suggested engineering strategies as a 'means to prevent or to mitigate the evil effects of floods'.$^{98}$ Henderson identified a dam site, near where Wivenhoe Dam was eventually completed in 1984, but dismissed construction there as too expensive. Following his brief, Henderson designed three elaborate engineering schemes, proposing widening, deepening and regulating the Brisbane River. The corners at the bends were to be truncated. These measures would reduce flood heights, increase flood discharge rates and improve navigation (in nineteenth-century Brisbane, poor shipping channels were a substantial economic concern). These measures would significantly alter the river and require vast expenditure.

Henderson was first and foremost a colonial engineer. Presented with the problem of controlling flood waters, he utilised his knowledge to devise structural engineering solutions to control nature, according to the dictates of his training and the demands of the electorate and political leaders. However, at the end of his report, Henderson showed insight into the environmental problem that colonial settlement had created.

95 Cossins, 'Ghosts of the 1893 Flood', 6.

96 Cyrus Williams, 'On some effects of Land Floods in a Tidal River', Minutes of the Proceedings of the Institution

of Civil Engineers 145 (1901): 334-39; Cossins, 'Early Hydrology of the Brisbane Area', 8.

97 'Government and Floods', Brisbane Courier, 10 January 1894, 4.

98 Henderson, 'Floods in Brisbane River', 307. 
He 'strongly' advised that 'steps be immediately taken to prevent the erection, on low-lying flooded lands along the river banks below the city, of buildings of every kind, and also of all other structures that would retard the flow of flood waters'. ${ }^{99}$

Henderson's advice to vacate the floodplains was not only insightful, but also a rare voice in the clamouring demands for flood prevention, rather than controls on urban development. It is this recommendation, albeit at the end of a lengthy report of suggested engineering solutions, that I suggest is evidence of a complex relationship between the engineer and the environment.

Consequently, it is valid to conclude that John Baillie Henderson was very much a nineteenth-century British engineer, with a training and value system that justified structural control of the environment, in this case water measurement and management to control floods. An assessment of Henderson's work could simply dismiss him as a servant of the state, employed to ensure water supply and flood mitigation for Queensland. Yet through state-funded research undertaken by Henderson, the colony departed from British hydrological models and began to recognise the climatic complexities of a subtropical environment. His insistence on obtaining local data through stream gauging and rainfall monitoring added substantially to knowledge of the local hydrology and weather patterns. Similarly, his recommendations to build flood gauges, create a flood-warning system, raise telegraph lines and vacate the floodplain added notions of non-structural solutions to the human-created hazard of flooding.

This case study draws out growing settler understandings of the environment in late nineteenth-century Queensland at the intersection of science, state and the lay public in the south-east of the colony. Henderson worked closely with local landholders and residents through the publication of his research and reports in newspapers, as well as through participating in public meetings and liaising with other government bureaucracies. These endeavours served to engage the populace with the practice of scientific activity and to circulate an emerging environmental knowledge. By the engagement of local gauge readers and distribution of standardised recording forms, diagrams and maps, Henderson increased both the state's hydrological data and scientific and settler knowledge.

Under Australia's constitution, water resources, unlike meteorology, have remained a state concern, still tied to state imperatives of development and water security. The work of Henderson, as the recorder and codifier of rainfall, run-off and flood behaviour, remains the baseline data that informs current water management decisions in Queensland. With Federation in 1901, this knowledge of local hydrological and meteorological complexities formally joined intercolonial expertise

99 Henderson, 'Floods in Brisbane River', 307. 
when state agencies transferred their responsibilities to the new Australian Bureau of Meteorology in 1908. Local imperatives to increase settlers' knowledge became a concern for the young nation. Henderson's state government department expanded local and national understandings of the environment and contributed to the growing networks of transnational science at the turn of the twentieth century. 
This text is taken from International Review of Environmental History, Volume 4, Issue 1, 2018, edited by James Beattie, published 2018 by ANU Press, The Australian National University, Canberra, Australia.

doi.org/10.22459/IREH.04.01.2018.06 